Jahangirnagar University J. Biol. Sci. 5(2): 1-10, 2016 (December)

\title{
Screening of $\alpha$-amylase producing bacteria from tannery wastes of Hazaribag, Bangladesh
}

\author{
Md. Rayhan Islam, Omit Kumer Mondol ${ }^{1}$, Md. Saimoon Rahman, Md. Morsaline \\ Billah, Mohammad Shahedur Rahman ${ }^{1}$ and Umme Salma Zohora ${ }^{1 *}$ \\ Biotechnology and Genetic Engineering Discipline, Khulna University, Khulna-9208, \\ Bangladesh
}

\begin{abstract}
Alpha amylases ( $\alpha$-amylases) are one of the most imperative enzymes for producing simple sugar units from complex sugar molecules. Attempts were made to isolate amylolytic bacterial strains from soil samples of tannery wastes collected from Hazaribagh, Dhaka and subsequent partial characterization was performed. Bacterial isolates were primarily screened for $\alpha$ amylase activity on starch agar medium. Based on microscopic and biochemical properties of isolates, $\alpha$-amylase activity of bacterial isolates were determined to find out two best producers of the enzyme. Subsequent molecular identification of these two $\alpha$-amylase producing bacterial isolates using 16s rRNA sequence analysis showed that isolates were Bacillus amyloliquefaciens and B. subtilis respectively. In submerged fermentation the $B$. amyloliquefaciens showed the highest activity $(2.13 \mathrm{U} / \mathrm{ml})$ while $B$. subtilis showed the second highest activity $(1.89 \mathrm{U} / \mathrm{ml})$. Characterization of the enzyme produced by $B$. amyloliquefaciens revealed that the maximum activity demonstrated at incubation time $25 \mathrm{~min}, \mathrm{pH} 7.0$ and temperature $50^{\circ} \mathrm{C}$. This newly isolated $B$. amyloliquefaciens could be exploited for the industrial production of $\alpha$-amylase with commercial implications.
\end{abstract}

Key words: $\alpha$-amylase producing bacteria, 16 s rRNA sequence, tannery wastes.

\section{INTRODUCTION}

Now-a-days industrial production and use of enzyme is increasing due to the increase of number of industries especially in food, beverage, textile, leather and paper industries and the issues are related to environmental safety. The current world market for industrial enzymes is estimated to be US $\$ 1.6$ billion which are distributed among food enzymes (29\%), feed enzymes (15\%) and general technical enzymes (56\%) (Outtrup et al., 2002). Alpha-amylases are one of the main enzymes used in these industries (Swain et al., 2006). These enzymes are of great significance in biotechnology, constituting a class of industrial enzymes having approximately $25 \%$ of the world enzyme market (Rajagopalan $\&$ Krisnan, 2008). In particular, $\alpha$-amylase catalyzes the hydrolysis of internal $\alpha-1$, 4glycosidic linkages in starch to produce low molecular weight products, such as glucose, maltose and maltotriose units (Gupta et al., 2003). They can be obtained from several sources, such as plants, animals and microorganisms. Microbial origin of $\alpha$-amylases could be ideal source for production of the enzyme in a cost effective manner than while compared to plant and animal sources (Tanyildizi et al., 2005). Several fungi, yeasts and

\footnotetext{
${ }^{1}$ Department of Biotechnology and Genetic Engineering, Jahangirnagar University, Savar, Dhaka1342, Bangladesh

* Corresponding author. E-mail: zohoraus@bgeju.edu.bd
} 
bacteria have reported to produce $\alpha$-amylases (Das et al., 2011). The members of the genus Bacillus $s p$. producing extracellular $\alpha$-amylases are of particular significance in industrial applications. Scientists are on continuous effort to isolate and identify the best producer strains of different extracellular enzymes as microbial prospecting offers significant advantages in discovering novel strains. Though microbes are versatile in their natural habitats, screening of non-conventional sources could offer microbes with unique potential. Conventional approaches of microbial screening coupled with molecular techniques serve as confirmatory basis of identification and subsequent modification. The present research work is focused on presumptive identification of $\alpha$-amylases producing bacteria from uncommon source, i.e. tannery wastes based on morphological and biochemical properties and subsequent molecular characterization of the selected $\alpha$ amylases producing strain. Furthermore, partial characterization of crude $\alpha$-amylase enzymes of the identified bacterial strains was conducted based on a number of properties influencing the optimum activity of the extracellular enzymes.

\section{MATERIALS AND METHODS}

Isolation of bacterial cultures: All the samples were collected from soil near tannery wastes found at East Asia Tannery, Hazaribagh, Dhaka, Bangladesh. Samples were kept in sterilized glass vials for further analysis. For the isolation of bacteria, soil samples were serially diluted and spread on skim milk agar plate. At first, samples were mixed with sterile $0.85 \% \mathrm{NaCl}$ solution and vortexed. Ten-fold serial dilutions were then carried out. It was followed by spreading $0.1 \mathrm{~mL}$ from each dilution aseptically on skim milk agar plates by using a glass spreader. The plates were incubated at $37^{\circ} \mathrm{C}$ in the incubator for 24 h. After $24 \mathrm{~h}$ incubation, clear zones were observed and differential growth patterns of bacteria were found in each skim milk agar plate. In this process, a small amount of inoculums from each morphologically different single colony were streaked onto the starch agar plate and incubated at $37^{\circ} \mathrm{C}$ for $24 \mathrm{~h}$.

Primary screening of $\alpha$-amylase producing bacteria and comparative analysis of $\alpha$ amylase activity: Bacterial isolates were screened for amylolytic properties by starch hydrolysis test on starch agar plate (Atlas et al., 1995). The microbial isolates were streaked as a line on the starch agar plate and then the plates were incubated at $37^{\circ} \mathrm{C}$ for $24 \mathrm{~h}$. After incubation, the plates were flooded with freshly prepared 1\% Lugol's iodine solution. Presence of the dark blue color in the plates indicated negative result while a clear zone of hydrolysis surrounding the growth indicated positive result. Thus, the isolates which produced clear zones of hydrolysis were considered as $\alpha$-amylase producers and the diameters of activity zones and colonies were measured in $\mathrm{mm}$ and recorded. Specific zones were calculated as the ratio of the diameter of the clear zones and diameter of colonies. 
Assessment of extracellular activity of enzymes: Isolated bacterial strains were cultured in $50 \mathrm{ml}$ starch liquid medium into a $250 \mathrm{ml}$ flask at $37^{\circ} \mathrm{C}$ for $24 \mathrm{~h}$ at $120 \mathrm{rpm}$ agitation. Cells were harvested by centrifuging at $8000 \mathrm{rpm}$ for $15 \mathrm{~min}$ and the supernatant was transferred to a fresh tube. Then, $20 \mu \mathrm{L}$ of supernatant was transferred to starch agar plates with antibiotics. After 24 hours the activity zones were measured in $\mathrm{mm}$ and recorded (Table 1.1).

Identification of potent $\alpha$-amylolytic bacterial isolates: A series of conventional biochemical tests were carried out for the identification of the genus of bacterial strains according to the Bergey's Manual of systemic bacteriology (Sneath et al., 1986).

The molecular identification was also done by $16 \mathrm{~S}$ rRNA gene sequencing. Two universal primer for 16s rRNA gene amplification were used for the purpose of PCR. 27F (AGAGTTTGATCMTGGCTCAG) was used as the forward primer while U1492R (GGTTACCTTGTTACGACTT) was used as the reverse primer. The 16s rRNA gene was sequenced using ABI 3700 Genetic Analyzer in the $1^{\text {st }}$ Base Laboratory SdnBhd, Malaysia. The 16s rRNA gene sequences were aligned using BioEdit7.2 software. The sample sequences were analyzed using BLAST-NCBI.

Inoculum preparation and submerged fermentation for $\alpha$-amylase production: For inoculum preparation, $50 \mathrm{ml}$ of nutrient broth medium was transferred to each of $250 \mathrm{ml}$ cotton plugged Erlenmeyer flask and sterilized in autoclave for $15 \mathrm{~min}$. After cooling at room temperature, $1 \mathrm{ml}$ of bacterial cultures was aseptically transferred to each flask. The flasks were loaded on a rotary shaking incubator at $150 \mathrm{rpm} 37^{\circ} \mathrm{C}$ for $24 \mathrm{~h}$.

Amylase production was carried out in sterile basal (Asgher et al., 2007) medium $(0.1 \%$ $\mathrm{KH}_{2} \mathrm{PO}_{4}, 0.25 \% \mathrm{Na}_{2} \mathrm{HPO}_{4}, 0.1 \% \mathrm{NaCl}, 0.2 \%\left(\mathrm{NH}_{4}\right)_{2} \mathrm{SO}_{4}, 0.005 \% \mathrm{MgSO}_{4} .7 \mathrm{H}_{2} \mathrm{O}, 0.005 \%$ $\mathrm{CaCl}_{2}$ ) containing $0.2 \%$ tryptone and $1 \%$ soluble starch. The initial $\mathrm{pH}$ of the medium was adjusted to 7.0. Erlenmeyer flasks $(250 \mathrm{ml})$ containing $50 \mathrm{ml}$ of medium were inoculated with $1 \mathrm{ml}$ of an overnight culture and incubated at $37^{\circ} \mathrm{C}$ in a rotary shaker incubator at $150 \mathrm{rpm}$ for $48 \mathrm{~h}$.

Separation of cells from culture media: After incubation, fermented broth was centrifuged at $4^{\circ} \mathrm{C}, 8000 \mathrm{rpm}$ for $15 \mathrm{~min}$ in a cooling centrifuge. Supernatant was collected and preserved or used for enzyme assay.

Determination of $\alpha$-amylase activity: Assay for $\alpha$-amylase was performed the 3,5 dinitrosalicylic acid (DNS) method (Miller, 1959) and $\alpha$-amylase activity was measured (Bernfeld, 1955). At first, a fresh solution of $0.5 \%$ soluble starch solution was prepared by dissolving $0.5 \mathrm{~g}$ soluble starch in $100 \mathrm{~mL} 0.02 \mathrm{M}$ sodium phosphate buffer $(\mathrm{pH}$ 6.9) (Gomes et al., 2001). Then $0.5 \mathrm{~mL}$ enzyme solution was diluted into $1 \mathrm{~mL}$ distilled water and $0.2 \mathrm{~mL}$ starch solution was added and incubated at $37^{\circ} \mathrm{C}$ for $5 \mathrm{~min}$. Then, $3 \mathrm{~mL}$ DNS reagent was added subsequently. The solution was kept in a boiling water bath at $90^{\circ} \mathrm{C}$ or $15 \mathrm{~min}$ and then under running tap-water to cool down at room temperature. Next, $10 \mathrm{~mL}$ distilled water was added into it. The absorbance was measured at $540 \mathrm{~nm}$ with UV-Vis 
spectrophotometer (Optizen pop, Mecasys Co., Ltd., Taiwan). One unit (U/mL) of $\alpha$ amylase activity is defined as the amount of $\alpha$-amylase required to liberate $1 \mathrm{mg}$ of reducing sugar (maltose) from starch/min, under the assay conditions.

Effect of cultivation period for $\boldsymbol{\alpha}$-amylase production: The effect of cultivation period on the production of $\alpha$-amylase was investigated by carrying out fermentation for $72 \mathrm{~h}$ at $37^{\circ} \mathrm{C}$ as a measure of optimization of culture conditions. The sample was collected every $24 \mathrm{~h}$ to observe the production of enzymes. The $\mathrm{pH}$ and volume of the medium were 7.0 and $50 \mathrm{ml}$ respectively and the assay was carried out with reaction period of $5 \mathrm{~min}$.

Partial characterization of crude $\boldsymbol{\alpha}$-amylase: The activity of $\alpha$-amylase was determined by conversion of starch into simple sugars. A fresh solution of $0.5 \%$ starch was prepared by dissolving $0.5 \mathrm{~g}$ soluble starch in $0.02 \mathrm{M}$ sodium phosphate buffer ( $\mathrm{pH}$ 6.9) to obtain a $100 \mathrm{~mL}$ solution. $0.2 \mathrm{~mL}$ of the prepared starch was transferred into test tubes along with $0.5 \mathrm{ml}$ of the $\alpha$-amylase and incubated accordingly. The amount of reducing sugar was determined by DNS method (Miller, 1959). To investigate the optimum incubation time of the $\alpha$-amylase, reaction was carried at different time intervals $(5,10,15,25,30$ and 60 $\mathrm{min}$ ) and the enzyme activities were recorded. In addition, for determination of optimum temperature for maximum activity of the crude $\alpha$-amylase, the enzyme samples were incubated for $5 \mathrm{~min}$ at temperature ranging from $30^{\circ}$ to $90^{\circ} \mathrm{C}$. Again, optimum $\mathrm{pH}$ on activity of crude $\alpha$-amylase was determined using different buffer systems in the $\mathrm{pH} 6.0$ $10.0(0.2 \mathrm{M}$ glycine- $\mathrm{NaOH}$ buffer and $0.2 \mathrm{M}$ sodium phosphate buffer). Then the enzyme activity was determined and the assay was carried out for an incubation period of $5 \mathrm{~min}$.

\section{RESULTS AND DISCUSSION}

Isolation of bacterial strains and primary screening of $\alpha$-amylase producer: In industrial production of enzymes and their biotechnological applications, the key is always the choice of the appropriate microorganisms. Isolation and selection of suitable organisms are very essential for the production of extracellular amylases. Members of genus Bacillus were found to be better producer of different types of $\alpha$-amylases (Nusrat and Rahman, 2007). In this connection, 36 bacterial isolates were found in initial screening from soil samples of tannery wastes. Among them, 8 of the isolates were found to be protease producing while 12 of them were capable of producing $\alpha$-amylases. Interestingly, all of the protease producers possessed the ability of producing $\alpha$-amylases and produced $\alpha$-amylases into the media. The comparison of $\alpha$-amylase activity the isolates were demonstrated on starch agar plate and clear zone were observed after treatment with Lugol's iodine solution in a method described earlier (Suman \& Ramesh, 2010). The diameters for the clear zones were measured in millimeters ( $\mathrm{mm}$ ) and presented in Table 1.

Among 8 tested bacterial isolates, 2 amylase producing bacteria IBLR204 (top amylase producer), IBLR82 (top amylase producer among proteolytic strains) were selected for further biochemical studies and subsequent molecular identification. 
Table 1. The diameter of clear zones by different bacterial isolates on starch agar medium

\begin{tabular}{l|c|c}
\hline \multicolumn{1}{c|}{ ID No. } & $\begin{array}{c}\text { Diameter } \\
(\mathrm{mm}, \text { Mean } \pm \text { SE; } \mathrm{n}=3)\end{array}$ & Specific zone \\
\hline IBLR201 & $26 \pm 1.125$ & 1.40 \\
IBLR202 & $26.43 \pm 1.435$ & $\mathbf{1 . 5 7}$ \\
IBLR203 & $27.19 \pm 1.745$ & 1.17 \\
IBLR204 & $28.16 \pm 1.086$ & 1.59 \\
IBLR31 & $23.26 \pm 1.003$ & 1.27 \\
IBLR71 & $22.90 \pm 0.984$ & 1.21 \\
IBLR82 & $24.56 \pm 1.235$ & 1.41 \\
IBLR122 & $24.08 \pm 2.996$ & 1.38 \\
\hline
\end{tabular}

IBL stands for Industrial Biotechnology Laboratory while R for the person conducting experiments

Assessment of extracellular activity of enzyme: Submerged fermentation was carried out for $\alpha$-amylase production as reported earlier (Riaz et al., 2009). Among 2 isolates, IBLR204 was found to be better producer of $\alpha$-amylase than IBLR82 (Table 2). Therefore, the results indicated that despite collected from same source, IBLR204 strain only produced amylase while IBLR82 strain produced both the enzymes ( $\alpha$-amylase and protease). However, the proteolytic activity of IBLR82 strain was also found to be high. As IBLR204 was the best $\alpha$ amylase producer, it was selected for further investigation for partial characterization of $\alpha$-amylase. However, both the strains were subjected to molecular identification.

Table 2. Assessment of extracellular activity of enzyme produced by two isolates

\begin{tabular}{c|c}
\hline ID No. & $\begin{array}{c}\text { Diameter } \\
(\mathrm{mm}, \text { Mean } \pm \text { SE; } \mathrm{n}=3)\end{array}$ \\
\hline R204 & $24.91 \pm 1.535$ \\
R82 & $22.53 \pm 1.238$ \\
\hline
\end{tabular}

Biochemical and molecular identification of selected isolates: The biochemical identification of the selected isolates was performed according to the Bergey's manual of systemic bacteriology (Sneath et al., 1986) and both of the isolates were presumptively identified as Bacillus sp. The biochemical test results are presented in Table 3.16S rRNA gene amplification and sequencing was previously described as means of identifying as well as characterizing Bacillus sp. (Gomma \& Momtaz, 2007). The use of molecular techniques along with the microscopic and biochmical methods, adds more precision and accuracy to the phylogenic identification and also to the true reflection of microbial diversity. 
Table 3. Results of different morphological and biochemical tests of the isolates

\begin{tabular}{|c|c|c|}
\hline Name of the test & IBLR204 & IBLR82 \\
\hline Gram reaction & + & + \\
\hline Shape of the cell & Rod & Rod \\
\hline $\begin{array}{l}\text { Catalase /Gelatin /Starch hydrolysis / Voges-Proskauer/ } \\
\text { Nitrate reduction/ } 10 \% \mathrm{NaCl}\end{array}$ & + & + \\
\hline $\begin{array}{l}\text { Methyl Red / Oxidase / Indole / Growth on } \\
\text { MacConkey agar }\end{array}$ & - & - \\
\hline \multicolumn{3}{|c|}{ Carbohydrate fermentation test (acid production) } \\
\hline D-Glucose & - & + \\
\hline D-Fructose & - & + \\
\hline Sucrose & - & + \\
\hline Mannitol & - & - \\
\hline Maltose & - & - \\
\hline Lactose & - & - \\
\hline \multicolumn{3}{|c|}{ Carbohydrate fermentation test (Gas production) } \\
\hline D-Glucose/ D-Fructose/ Sucrose/ Mannitol/ Maltose & - & - \\
\hline
\end{tabular}

According to 16S rRNA gene sequence analysis, bacterial strains R204 and R82 were identified as B. amyloliquefaciens and B. subtilis, respectively.

Effect of incubation period on enzyme production: Optimization of culture conditions is very important for maximum microbial growth and enzyme production by microorganisms (Kathiresan \& Manivannan, 2006). From the time course study in shake culture it was found that the rate of enzyme increased with the duration of fermentation and reached its maximum activity after incubation of $48 \mathrm{~h}$ (Fig. 1). A prolonged incubation time beyond $48 \mathrm{~h}$ did not increase the enzyme production. These finding are similar to the result reported by (Haq et al., 2010). The reducing sugars were measured by adding 3, 5-dinitro salicylic acid reagent, using maltose as standard (Miller, 1959) and the enzyme activity of crude enzyme was calculated as $2.13 \mathrm{U} / \mathrm{ml} / \mathrm{min}$. This enzyme fermentation was not optimized properly and showed less activity in comparison to previous studies on B. subtilis (Riaz et al., 2003). 


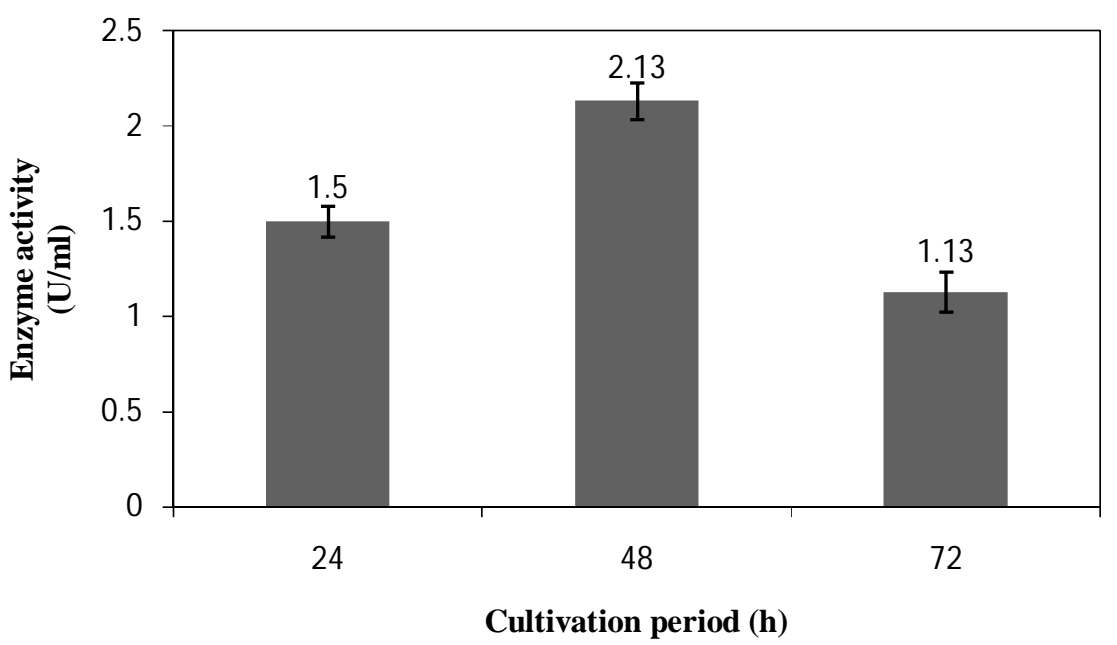

Fig. 1. Effect of cultivation period on $\alpha$-amylase production by IBLR204

Effect of incubation time on activity of crude $\alpha$-amylase: The maximum activity for the extracellular enzyme produced by IBLR204 was observed at 25 min which was recorded approximately as $2.34 \mathrm{unit} / \mathrm{ml} / \mathrm{min}$ (Fig. 2). However, activity appeared to decrease gradually if the incubation period was further extended.

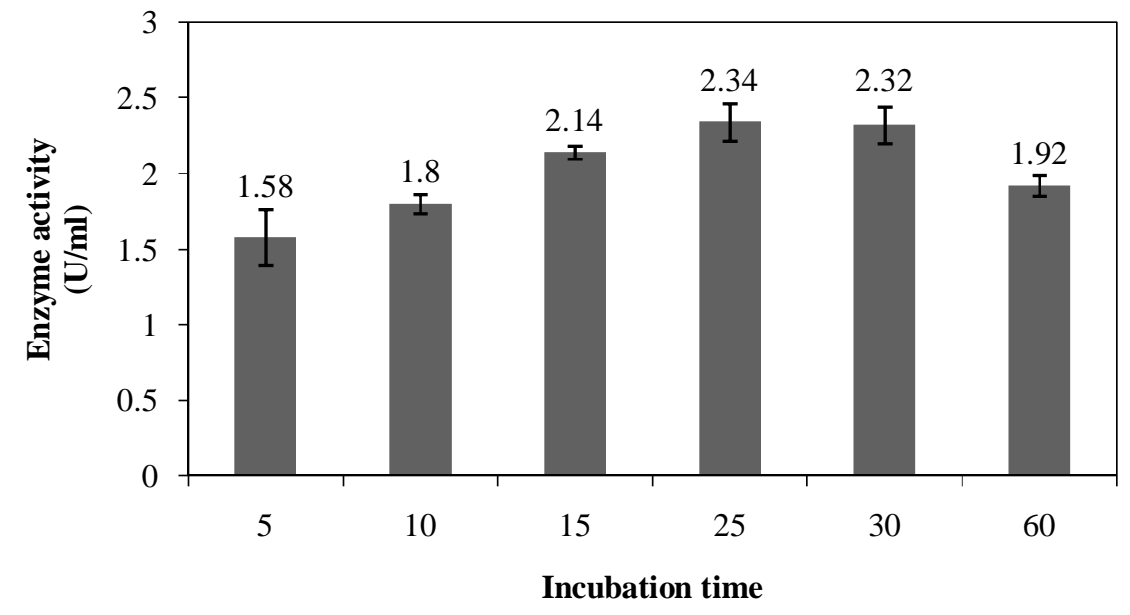

Fig. 2. Effect of incubation time on activity of crude $\alpha$-amylase

Effect of temperature on activity of crude $\alpha$-amylase: The optimum temperature for $\alpha$ amylase activity is usually related to the growth temperature of the microorganisms. However, it was also reported that extracellular enzymes were optimally active at temperature above and beyond the host organism's optimum growth temperature (Vieille and Zeikus, 2001). A temperature range of 40 to $60^{\circ} \mathrm{C}$ was found promising with $50^{\circ} \mathrm{C}$ 
optimum for activity of $\alpha$-amylase produced by B. amyloliquefaciens (Fig. 3) which was comparable previous findings (Demirkan et al., 2005).

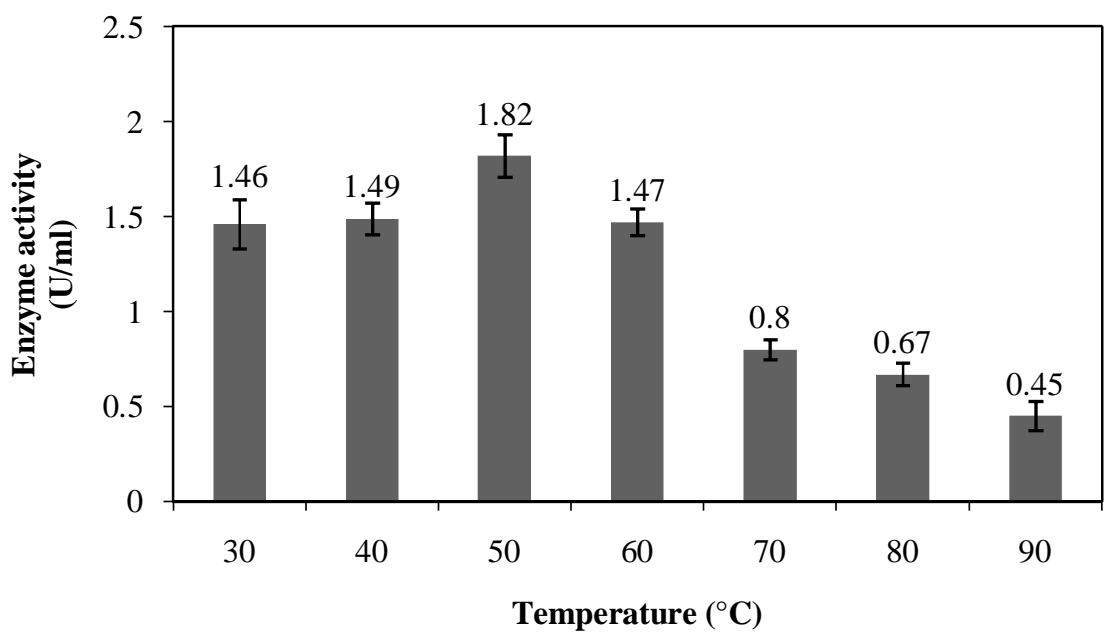

Fig. 3. Effect of Temperature on activity of crude $\alpha$-amylase

Effect of pH on activity of crude $\boldsymbol{\alpha}$-amylase: The enzyme exhibited high activity in acidic or neutral conditions with the optimal pH 7.0 (Fig. 4) which is within the range of values for most starch degrading bacterial strains (Gupta et al., 2003). Regarding to Bacillus genus, $\alpha$-amylase enzymes with optimum activities at $\mathrm{pH}$ values was as low as 3.5 or as high as 10.6 as previously reported (Hayashi et al., 1988).

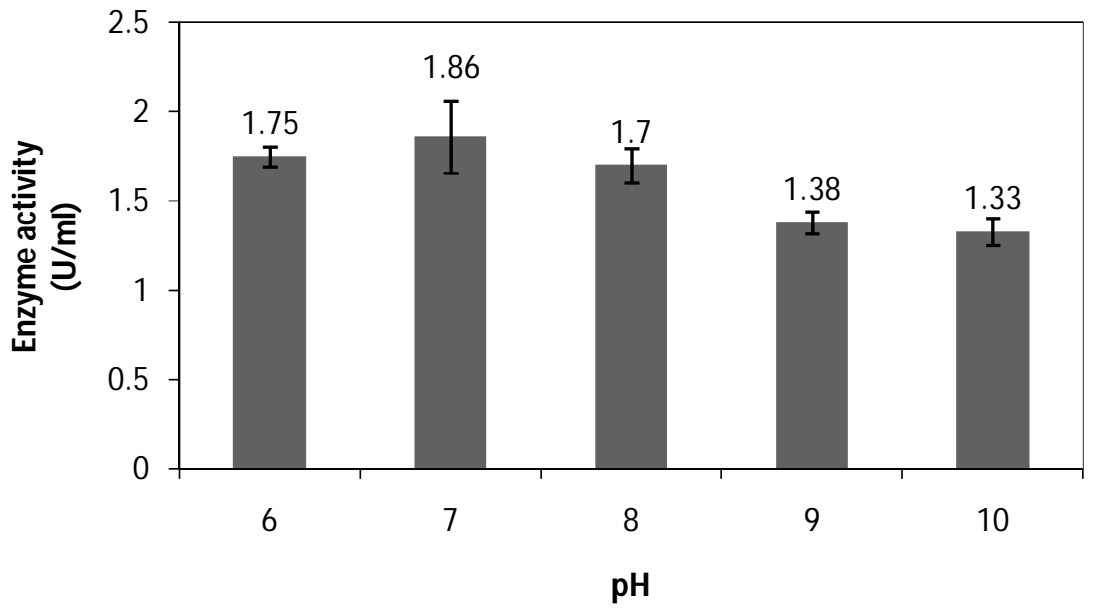

Fig. 4. Effect of $\mathrm{pH}$ on activity of crude $\alpha$-amylase 
Bacterial species could be a good source for the production of $\alpha$-amylases and $B$. amyloliquefaciens (R204) could be a good candidate for $\alpha$-amylase production. The present study showed that $\alpha$-amylase from $B$. amyloliquefaciens had optimum $\mathrm{pH} 7.0$ and temperature $50^{\circ} \mathrm{C}$. Future work should employ the complete purification of $\alpha$-amylase so that higher specific activity could be achieved. Again, further characterization of the enzyme could provide information structure function relationship and elucidate the mechanism of action. This would open up a possibility for genetic improvement of $\alpha$ amylase producing strains, the enzyme and their subsequent utilization in the related industries.

Acknowledgement: The authors would like to acknowledge the funding from INSPIRE project supported by British Council, Bangladesh.

\section{REFERENECES}

Asgher, M., Asad, M. J., Rahman, S.U. and Legge, R. L. 2007. A thermostable $\alpha$-amylase from a moderately thermophilic Bacillus subtilis strain for starch processing, Journal of Food Engineering, 79 (3): 950-955.

Atlas, R. M., Parks, L. C. and Brown A. E. 1995. Laboratory Manual of Experimental Microbiology. by Mosby-Year Book Inc., St Louis.

Bernfeld, P. 1955. Amylases, $\alpha$ and $\beta$. Methods in Enzymology. 1: 149-158.

Das S., Singh S., Sharma V., Soni M.L. 2011. Biotechnological applications of industrially important amylase enzyme. International Journal of Pharma and Biosciences, 2(1): 486496.

Dermirkan, E. S., Mikami, B., Adachi, M., Higa, T. and Utsumi, S. 2005. $\alpha$-amylase from Bacillus amyloliquefaciens: purification, characterization, raw starch degradation \& expression in E. coli. Process Biochemistry 40(8): 2629-2636.

Gomes, I., Sultana, M., Uddin, K., Gomes, J., Steiner, W. and Gomes, D. J. 2001. Nutrient composition and fermentation conditions for $\alpha$-amylase production by Bacillus amyloliquefaciens. Bangladesh Journal of Microbiology. 18(2): 141-150.

Gomma, O. M. and Momtaz, O. A. 2007. 16s rDNA characterization of a Bacillus isolate and tolerance profile after subsequent subculturing. Arabian Journal of Biotechnology. 10(1): 107-116.

Gupta, R., Gigras, P., Mohapatra, H., Goswami, V. K. and Chauhan, B. 2003. Microbial $\alpha-$ amylases: a biotechnological perspective. Process Biochemistry. 38(11): 1599-1616.

Haq, I., Ali, S., Javed M.M., Hameed, U., Saleem, A., Adnan, F. and Qadeer, M.A. 2010. Production of alpha amylase from a randomly induced mutant strain of Bacillus amyloliquefaciens and its application as a desizer in textile industry.Pakistan Journal of Botany. 42(1): 473-484.

Hayashi, T., Abiba, T. and Horikosh, K. 1988. Properties of a new alkaline maltohexose forming amylase. Applied Microbiology and Biotechnology. 28(3): 281-285.

Kathiresan, K. and Manivannan, S. 2006. $\alpha$-amylase production by Penicillium fellutanum isolated from mangrove rhizosphere soil. African Journal of Biotechnology. 5(10): 829-832.

Miller, G.L. 1959. Use of dinitrosalisylic acid reagent for determination of reducing sugar. Analytical Chemistry. 31(3): 426-428.

Nusrat, A. and Rahman, S.R. 2007. Comparative studies on the production of extracellular $\alpha$ amylase by three mesophilic Bacillus isolates. Bangladesh Journal of Microbiology. 24(2): 129-132. 
Outtrup, H. and Jorgensen, S.T. 2002. The importance of Bacillus species in the production of industrial enzymes. In Applications and systems of Bacillus and relatives. Edited by R. Berkley, Blackwell Science Inc., Malden. 206-218.

Rajagopalan, G. and Krishnan C. 2008. Alpha-amylase production from catabolitederepressed Bacillus subtilis KCC103 utilizing sugarcane bagasse hydrolysate. Bioresources Technology. 99(8): 3044-3050.

Riaz, N., Haq, I.U. and Qadeer, M.A. 2003. Characterization of $\alpha$-amylase by Bacillus subtilis. International Journal of Agriculture and Biology. 5(3): 249-252.

Suman S, Ramesh K (2010) Production of a thermostable extracellular amylase from thermophilic Bacillus species. Journal of Pharmaceutical Sciences and Research 2:149-154.

Sneath, H.A., Peter, M.S., Nicolas, H. and Hold, G.L. 1986. Bergey's Manual of Systemic Bacteriology. (1 \& 2).

Swain, M.R., Kar, S., Padmaja, G. and Ray, R.C. 2006. Partial characterization and optimization of production of extracellular $\alpha$-amylase from Bacillus subtilis isolated from culturable cow dung microflora. Polish Journal of Microbiology 55(4):289-296.

Tanyildizi, M.S., Ozer, D. and Elibol, M. 2005. Optimization of $\alpha$-amylase production by Bacillus sp. using response surface methodology. Process Biochemistry. 40(7): 2291-2296.

Vieille, C. and Zeikus, G. J. 2001. Hyperthermophilic enzymes: Sources, uses \& molecular mechanisms for thermostability. Microbiology and Molecular Biology Reviews 65(1): 143 